\title{
The Ethnoarchaeology of a Swedish Village
}

Stig Welinder

\begin{abstract}
The village of Nyberget, Dalarna, Central Sweden, during the 19th century is studied from an ethnoarchaeological point of view. The dynamic flexibility and ambiguity of the cultural landscape of the village and its households are stressed. This is understood in relation to economic structure and gender roles. The concepts used in understanding the historical village form a challenging starting-point for understanding a prehistoric cultural landscape.
\end{abstract}

Stig Welinder, Department of Archaeology, Uppsala University, Gustavianum, S-753 IO Uppsala, Sweden.

In the minds of foreigners, Swedish folklore centers on Midsummer Night, the province of Dalarna, and fair-haired maidens. At least that is the common belief among Swedes.

Anyhow, an unmarried girl who climbs seven fences and puts seven different flowers under her pillow during Midsummer Night will dream about her future husband. Alternatively, she might sit on top of the roof-ridge of a house that has been thrice moved, or she might naked sweep the floor from the door inwards (Eskeröd 1965:112-116). This article is about the kind of cultural landscape, where these methods of fortune-telling work: a landscape of cattle-breeding with a wealth of fences, where the houses were frequently moved, and where marriage was essential to the girls in as much as they expected to become housewives responsible for cleaning the house, although their sexuality and choice of husband were controlled by others.

The article presents an ethnoarchaeological study (Welinder 1992a, b) of a village in the mining district (Sw. Bergslagen) in the southern part of Dalarna. It is an attempt to understand a cultural landscape in a way that may be of interest for the understanding of prehistoric cultural landscapes.

\section{ARCHAEOLOGY, SCIENCE, AND ETHNOARCHAEOLOGY}

Archaeology is not a science, and it is not "anything goes" (Patrick 1985, Kelley \& Hanen 1988, Watson 1991 are a few introductions to the current Anglo-American debate). In my view it is an intersubjective discussion on what humans are, on how to understand human variability. And, of course, it is the study of prehistory.

Ethnoarchaeology is the field, in which concepts and terminology on how to understand the interaction between humans, things, and their environment, is most efficiently discussed. Thus, I see ethnoarchaeology more as a field of discussion and testing of concepts (Hodder 1986) than as a way towards ethnographic analogies or middle range theory (Binford 1983). The ultimate goal, of course, is to find concepts of interest when trying to understand the prehistoric record (Gould 1989).

I have lived close to a decade in the village of Nyberget. The following ethnoarchaeological study is based on archaeological fieldwork, the reading of historical documents, and on my experience as a participant in village life and as a listener to the 
talk and gossip among the villagers. It is a true post-modern mixture of past and present.

The key concepts are dynamic flexibility, ambiguity, and fixed tradition.

\section{THE VILLAGE OF NYBERGET}

Nyberget is a village in Stora Skedvi parish in the southern part of Dalarna, about $30 \mathrm{~km}$. from the town of Falun (Fig. 1). Today it has about 65 inhabitants, most of whom work in nearby population centres. During summer the number of inhabitants is doubled.

Along a south-north ecological gradient, the southern part of the parish is an agricultural district with prosperous farms along the Dalälven river-valley, the middle part is a farming and handicraft district, and the northern part is a mining district with additional small-scale farming. The latter part also was the summer grazing area for the cattle of the farms in the southern and middle parts of the parish.

The village was established as a permanent settlement consisting of scattered farms around a silver mine and a smeltery in the mid-15th century. The mine never produced much silver, at least compared to the Sala mine, and periodically it produced nothing at all. The mine was in operation until 1878 . After that it was run on a low scale merely to prevent damage except during the two World Wars, when full-scale operation was profitable again. Since 1954 the mine has not been in use, and today the mine-shafts are inundated. The smeltery in Nyberget was closed in the early 17 th century, and the ore from then on was transported to a smeltery at the royal estate of Lövåsen a few kilometers away, which also owned the mine.

The population of the village was at its maximum about 1820, when it comprised approximately 200 persons. At that point it had doubled in about 150 years

Fig. 1. The farms and cottages of the village Nyberget according to the 1856 map (Laga skiftet).

Big dots = farms; small dots $=$ cottages; triangles $=$ mines; square $=$ the drying house;

$B=$ the farm Backans;

$D=$ the närfäbod Dalbo:

$F=$ the farm Fäbo;

$H=$ the farm Hinriks;

$G=$ the cottage Granströms;

$J=$ the farm Jutens. 
and was to be halved in about another 150 years. After the final closing of the mine in 1954 the population rapidly declined from about 120 to about 60 persons.

The population was a mobile one. People moved in and out of the village according to varying booms and slumps in the mining and metal-working industry. During the entire timeperiod, for which a reasonable accurate census exists, more people moved out of the village than into it. Especially the young girls could find no work as house- and stablemaids at the small farms in the village. They had to move to bigger farms in other parts of the parish or to the neighbouring parishes and nearby towns. The boys, on the other hand, more easily found work in the mine, smeltery or woods, where there always was a need for woodsmen, charcoal-burners, and transporters of heavy loads.

Thus, Nyberget was a typical Bergslagen village with its economic basis in a mine and a smeltery and a number of small farms owned by families. These farms had a little arable land and cattle, but the adult males of the farms also worked in the industries and the forest. According to the 1647 tax-list, the freeholders among the farmers paid their tax in a fixed quantity of charcoal to be delivered to the royal smeltery at Lövåsen. During the 19 th century an increasing part of the land in the village was owned by companies and accordingly rented by the farmers.

It is to be noted that transhumance was not practiced by the Nyberget farmers. There was sufficient pasture-land close to the village during the entire year. On the contrary, pasture-land within the village during the second half of the 19th century was used for summer grazing by farms in other parts of the parish. Thus, part of the village consisted of shielings (Sw. fäbod) during these decades.

The Swedish word "fäbod" means a place, where the cattle grazed during the summer and where a girl lived alone in one or two small houses to tend the cattle and produce butter and cheese from the milk. The fäbodar in Nyberget were närfäbodar ( $\mathrm{Sw}$. nära = Eng. near) situated rather close to the permanent farms. At the närfäbodar the cattle were often tended by people from the farm going to and fro each morning and evening, while at a laingfäbod ( $\mathrm{Sw}$. laing = Eng. far away) the girl stayed by herself for weeks.

Nyberget can be characterized as a village with a flexible population in accordance with its mixed economy. A considerable part of its population were not landholders or farmers renting their farms but workers without property occupied in the mine, smeltery, or the forest. They lived with their families in cottages (Fig. 1).

\section{HUMANS, LANDSCAPE, AND HOUSES} In this section I will present a selection of field data and a discussion of them. Of course, it is a personal view, which aims at underlining the concepts I will argue for in the concluding part of this article. Is there any other way to do it?

The reader will note that much of my inspiration derives from feminist research (e.g. Moore 1986, Hjørungdal 1991). There are many ways of looking at the 19th-century cultural landscape discussed in Swedish research. For the reader acquainted with Swedish, the classic in historical ethnology is Erixon 1960, while a recent textbook is Blomkvist 1990.

Throughout the text I will write names as used in the village. People were, and still often are, called by their first name and the name of a farm in front of it. Thus, "Jut", or "Jutens", is the farm where Jut Arvid was born and lived as a boy. His parish register name was Arvid Eriksson (1883-1967). Fäbo Elin had moved into the village and got her name among the villagers from one of the farms where she lived in Nyberget. Her register name was Elin Sofia Jacobsson (1881-1968).

Many of the farms, perhaps all of the farms, of the village had a drying house (torkstuga or bastu in Swedish, the latter word is the word of the local Bergslagen dialect) 
in common (Fig. 1). This small building was used for drying threshed corn before going to the mill, for drying flax and malt, and for smoke-curing. It had a central stove without a chimney and shelves along the walls.

During the excavation of a drying house and the area in front of it, five buttons were found, three of which were found inside the house. One of these is an ordinary round and flat iron button with holes for the thread in the centre. The other two (Fig. 2) are balls of glass with a metal-loop for the thread. They are characteristic of the female frocks and blouses that were worn after that the traditional dress was abandoned in the beginning of the 19th century. The buttons found outside the house are flat metal buttons with a loop at the back side. They are characteristic of the traditional male dress and of the male working-clothes that came into fashion during the 19th century.

Thus, the excavation map of the drying house (Fig. 2) reveals an indicative gender pattern. The females watched and tended the fire in the stove and looked after the corn on

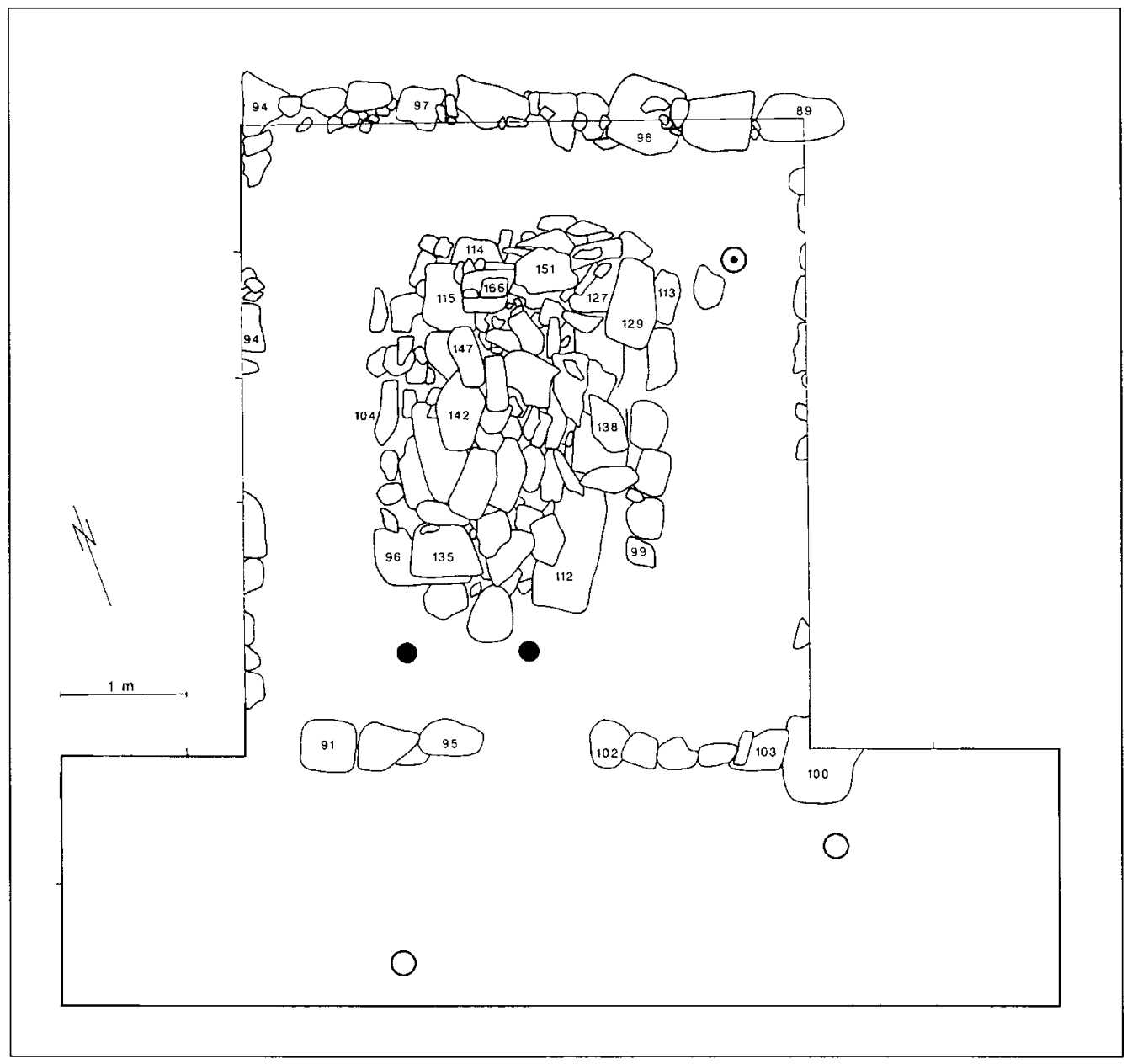

Fig. 2. The sill and oven of the village's drying house for threshed corn and the distribution of buttons within the excavated area inside and in front of the house. Dots = supposed female buttons, circles = supposed male buttons, dots-in-circles = indifferent buttons. 
the shelves, while the males transported the sacks of corn and large quantities of firewood to the house, using a horse and wagon or sledge.

Jut Arvid is a person who has stayed in the memory of many villagers. He is a person, about whom anecdotes are told. One reason may be that he never married. Accordingly, due to the strict gender pattern of the work-tasks of a farm, he had a female housekeeper. That was Fäbo Elin.

The farm rented by Jut Arvid was an agglomeration of two previous farms and one närfäbod (Fig. 3). For the moment I will concentrate on the fence dividing the farm into two parts. Of course, there was a physical fence, which prevented the cattle grazing in the pasture-land from entering the fields of the farm, but it was also the boundary between the cultivated and non-cultivated parts of the farm, and it was the dividing-line between a female and a male domain.

In the forested part of the farm Jut Arvid worked as a woodsman and charcoal-burner. In the cultivated part of the farm Fäbo Elin kept the household going, and in the evening she went out into the farmyard to call the cows. She had named the cows after the farmers, from whom she had bought them, so she was heard calling: "Löv Johan, Bur Kalle ..." The female was not supposed to interfere with the male's work in the forest. It is told among the villagers today that Jut Arvid had built his charcoal-burner's huts with such a narrow doorway that the rather stout Fabo Elin simply could not enter. From the farm Backans it is told that the girls entered the huts only briefly to deliver food to their father and brothers, who stayed for weeks in the huts while watching the charcoal-stacks.

In this way the village and its landscape may be seen as organized both functionally according to a mixed economy and socially according to a pattern of gender-specific worktasks. However, this is not the full understanding of the cultural landscape of Nyberget. It was a landscape formed by tradition but it

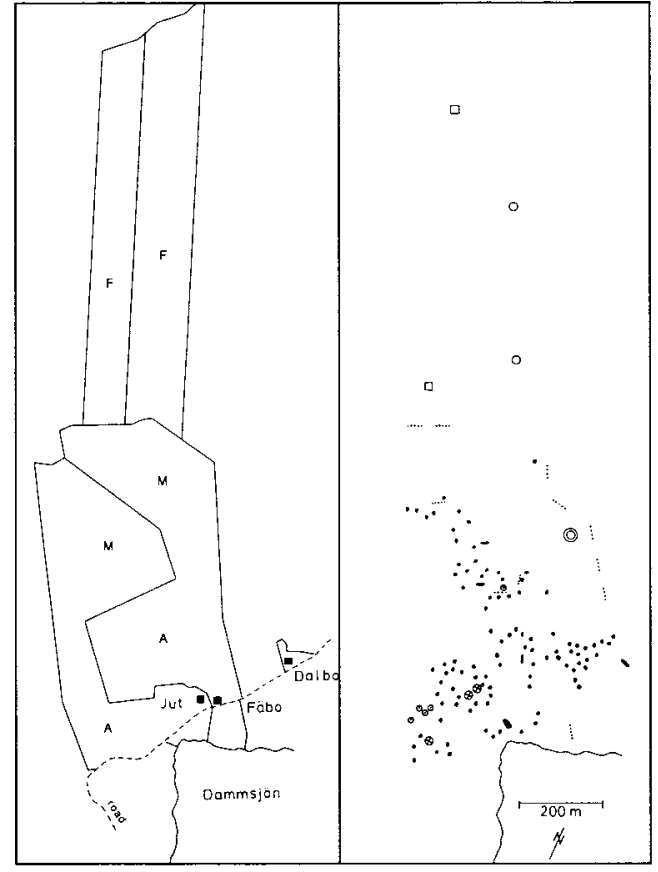

Fig. 3. The farms Jut and Fäbo and the fäbod Dalbo according to the 1856 map and the fossil cultural landscape recorded today. This was approximately the area rented by Jut Arvid Eriksson. $A=$ arable land $M=$ meadows, pasture land $F=$ forest $;$ dotted lines $=$ fences $;$ black dots = clearance cairns; dots - - -circles $=$ pits; crosses in-circles = limestone quarries; double circles $=$ mines; circles = charcoal stacks; squares $=$ charcoal stacks with a hut.

was not a fixed landscape.

The farms of the village were important units of economic production and self-evident units of social and demographic reproduction. A farm consisted of an agglomeration of some ten buildings around a farmyard. All farms had names, many of which are still in use. Normally, the exceptions were few, a farm was inhabited and tilled by a nuclear family. Some of the farms were kept by private landholders that had inherited them for generations within the same family. Other farms were kept by tenants. 
There is no permanent line of farms throughout the history of Nyberget. On the contrary, new farms could be established, and old farms could be abandoned, subdivided into two, or merged with another farm. Figure 4 presents an example of how two farms and a närfäbod have changed into one farm and two summer cottages during little more than a century. What is of importance in this example is not merely to note the flexibility of the landscape and its physical appearance, but that the area in Figure 4 is still talked about as three farms with different names. The concept "farm" is not an easy one within the village tradition since it comprises more than simply an economic and social unit of production and reproduction. It is also part of a tradition within the village. The remaining pages of this article hopefully will clarify this, if it can be understood by a nonvillager at all.

The flexibility of the landscape had its counterpart in the architecture of the individual houses. These were built as a timber box on a stone-sill, with a wooden roof. The box and roof could easily be transferred to another place, where a new sill was easily prepared. The houses could also easily be shortened, divided into two, or lengthened.
There are several examples of all four processes within the village during the last century (Fig. 5). The following story was told by an old woman, Sörmans Lina (1848-1936), early in this century, of how she settled into a newly erected house as a young housewife (Hage 1946:47):

I told Sörman that, even if I were to work night and day, we were to have a roof of our own above our heads and a floor of our own to stand on before the newborns arrived. Sörman glanced at me and said: "Well, you seem to have made up your mind!" He didn't say we, but I know that's what he meant. Sörman was like that. We bought Sömar Lisa's cottage in Klingsbo, pulled it down, and worked by the day for Finnbo Far and Hopp Vilhelm, who in return helped to transport the timber. We got land from Myggbo Jan and roof-trusses from Burns Johan.

The Swedish word "far" (Eng. father) is in this context used as a name denoting that the male head of the Finnbo farm was an elderly, respected man.

It is notable how the house was assembled from parts of various old houses and how it was easily built by the villagers themselves.

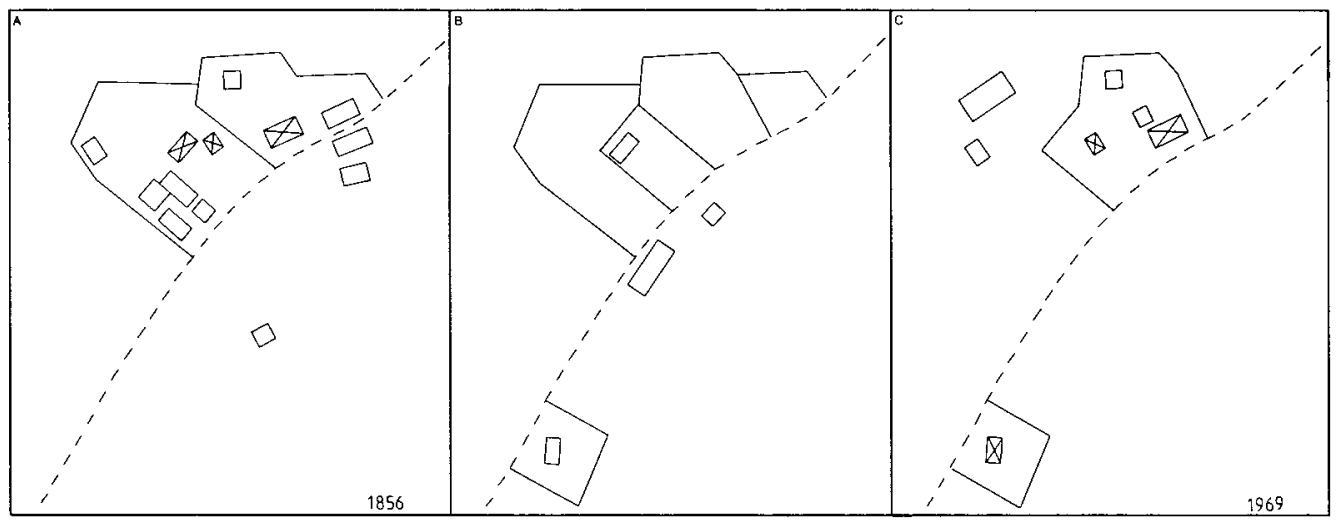

Fig. 4. The houses belonging to the farms Jut and Fäbo and the boundaries of the farmyards. A = the 1856 map (Laga skiftet); $B=$ stone sills of houses seen on neither of the maps and a summary of all documented boundaries between the farmyards; $C=$ the 1969 map (the economic map). Houses with a cross are dwelling-houses. 
The house built by Sörman - and Sörmans Lina - was, of course, to be named "Sörmans" (Eng. Sörman's) in the same way as his wife was called "Sörmans Lina". This was the normal way of naming houses after their owners or inhabitants. However, also the opposite was possible. Persons could be named after houses, as Fäbo Elin was among the villagers. This system of naming may be quite confusing.

A house could change its name, when it changed inhabitants. The house, which is today called "Örjas" after the present family of the house, has to my knowledge had the following earlier names: Fridhem, Gustafssons, Ingevalls, Skogvaktarns, Sprittens, Sätters. The inhabitants of the house accordingly were named "Ingevalls Anna", "Skogvaktarns Greta", "Spritt Inger" etc. Other houses could keep their name for generations or centuries. The name "Fäbo" is documented from the early 17th century and may be older still. Perhaps it indicates that a fäbod developed into an established farm during the 15th century. "Bengts" (the inflective possessive of the male first name "Bengt") is the traditional name of a house in the southern part of the village. Two generations ago the owner of that house moved into another in the central part of the village. Today that house is called "Bengts". Sometimes the two houses are referred to as "Nya Bengts" (Sw. ny = Eng. new) and "Gamla Bengts" (Sw. gammal= Eng. old). Most often Gamla Bengts is called "Holmgrens" after a later owner. Previous names of Nya Bengts are "Skräddars" and "Back".

It is not easy to predict the name of a house, when it changes inhabitants. Either the house or the inhabitants change their names. This is a rule with exceptions: Backans Berit today lives in the house "Flyttjegården". Both kept their names, when she moved into the house to start a family. The names of persons and houses are decided by the village talk, whereby the names are moulded.

Thus, the names may be ambiguous. They were not found in maps or registers used by

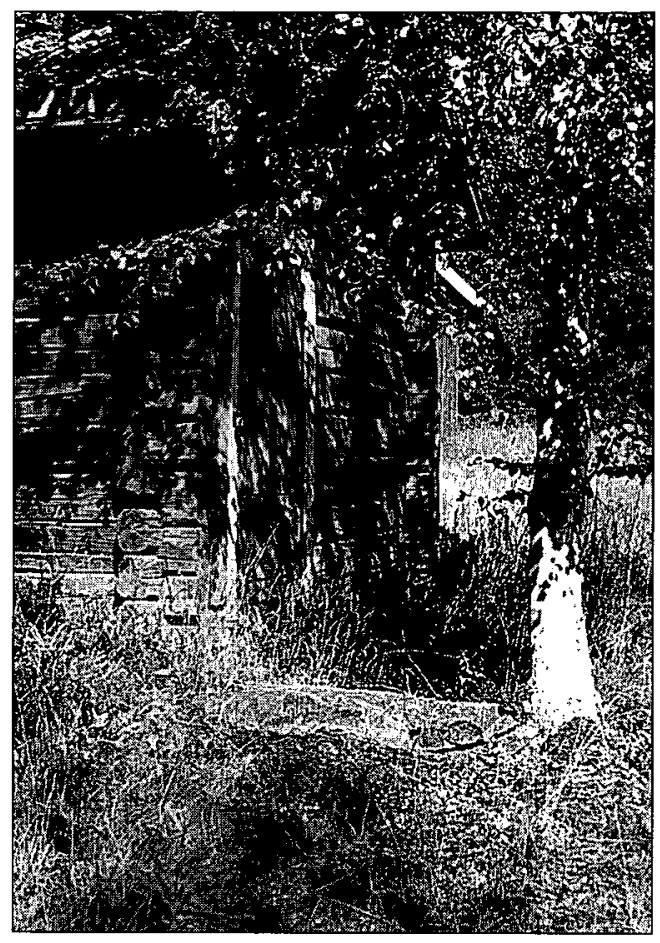

Fig. 5. A timbered house moved and rebuilt on a sill, which obviously has previously belonged to another house with quite another size and function. Photo Barbro Johnsen.

the villagers, but they were part of the daily life in the village, of people talking to one another and talking about one another.

Throughout the year the stock of cattle at the farm Backans grazed on various plots of pasture-land ( $\mathrm{Sw}$. hage, def. hagen, haga and hagan in the local dialect). Closest to the farmyard was a fenced plot simply called "Hagan" (Fig. 6). In my informants' youth it was used for sheep. Further away were $\mathrm{Ko}$ hagan (Sw. ko = Eng. cow) and Hästhagan (Sw. häst = Eng. horse). These hagar were also called "Björkhagan" (Sw. björk = Eng. birch) and "Asphagan" (Sw. asp= Eng. aspen). Thus, one and the same hage could be referred to by two different names by the inhabitants of Backans. The inhabitants of the neighbouring farms used other names for these 
hagar. At the farm Finnbo the one of Backans's hagar, which was closest to their farm, simply was called "Backans haga". At the farm Hinriks, on the other hand, the name "Backans haga" was used for a different hage close to the forested plot of Hinriks. That hage was named "Fölhagan" (Sw. föl = Eng. foal) by the Backans people (Fig. 6). The same name also could be used for several hagar in another way. At Finnbo the name "Hagan" was used for one of their hagar in the same way as the name was used at Backans for one of their hagar. This hage of Finnbo was usually called "Finnbo haga" among the rest of the villagers.

Thus, the names of the hagar within the village could only be understood in relation to the user of the name. The inhabitants of the various farms had different reference systems. One has to be a member of the circle of continuous talk within the village to understand what the names of houses, hagar, and other place-names within the village refer to.

Above I have used the word "house" when discussing place-names. Actually the villagers distinguish between "farms", "cottages", and "houses". The word "farm" (Sw. gård) has two meanings. It is an agricultural unit, and it is a place to live. In the former meaning the farm may or may not have a yard with a dwellinghouse that is inhabited today, but it has always had one (cf. Figs. 3-4). In the latter meaning the farm may or may not belong to an agricultural unit. Sometimes it is the dwelling-house of a previous farm, i.e, agricultural unit, that has lost its land, but the word "farm" is also used for a dwelling-house with a certain reputation due to its size, age, or inhabitants. A cottage is smaller than a farm or a house. It rarely is the dwelling-house of an agricultural unit, but it may once have been, if the farm has built a new dwelling-house or if there is just a small dwelling-house left in the yard of a previous farm (agricultural unit). The word "house" is most often used for rather new buildings or for dwelling-houses for two or more families. In fact it is difficult to predict what a new building or what an old building, which changes its status, will be

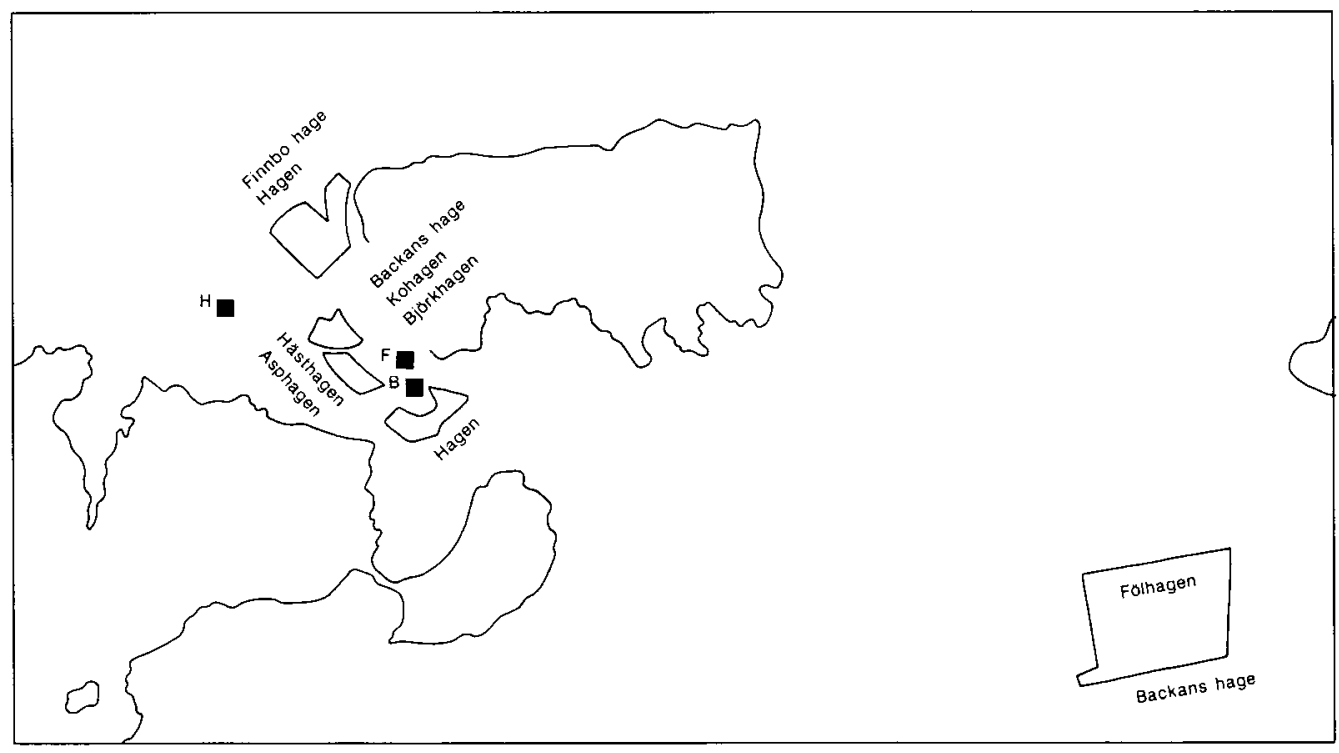

Fig. 6. The various names used for the fenced pasture-land belonging to the farms Backans and Finnbo. $B=$ Backans; $F=$ Finnbo; $H=$ Hinriks. 
called. This is decided in a subtle way in the continuous talk among the villagers.

Anders Gustafsson Granström certainly had a cottage built for himself and his family, when he moved into the village to become a worker at the smeltery in 1805 . He owned no land and purchased none. He simply built a cottage with one room surrounded by a lot big enough to grow potatoes and not much more. He chose to move to Nyberget some years after that he had started a family by marrying a girl from the village, while both of them worked in the town of Falun. The cottage, of course, got the name "Granströms".

The Swedish name "Granströms" (the inflective possessive of ("Granström"), thus, has to be translated as "Granströms" place", denoting both "Granström's cottage"(the cottage belonging to the male head of the family) and "the Granström family" (all the members of the family). The wife was called "Granströms Lisa" ("Lisa" being her first name), and both daughters and sons were known in a similar way, for example, "Granströms Johan" ("Johan" being the first name of a son).

The cottage Granströms was used by three patrilinear generations. The grandson Johan Granström moved out of the house in 1862, soon after he had started a family of his own, to become a worker at an ironworks near Falun. In the middle generation the house was inhabited by eight persons: a married couple, the wife's parents-in-law, and four children.

Thus, Granströms is an example of how the normative social pattern was established and reproduced in relation to the succession of generations and the change of jobs by the male heads of the nuclear families. The way that worktasks and the power was upheld within the social unit, i.e. the nuclear family, may be understood from the phosphate map (Fig. 7).

Granströms was a $22 \mathrm{~m}^{2}$ single-room cottage with an open fire-place and a door in the southern longwall. Later a small entrance was added. The phosphate map very clearly demonstrates (Fig. 7) how slops and scraps, night-soil, and all other kinds of waste were simply thrown out the door, or the slop-pail could be carried around the nearest corner of the house. This is easy to understand. There are few prehistoric sites that do not show the same pattern. However, the phosphate map may also be related to the specific organization of the family and its gender pattern and power relations.

Ethnoarchaeology normally is based on the participation of the researcher in the society studied. This is not possible in my kind of historical ethnoarchaeology. So far I have relied on a mixture of historical documents and my experience of the villagelife today, as well as the narrative accounts of old villagers about their youth half a century ago. With respect to the garbage removal, or rather the lack of it, during the 19th century I will cite a documentary report from the 1930s, when the life-pattern, in which the accumulation of the phosphate map at Granströms was an integral part, was on its way of breaking down. The document is "Lort-Sverige" (Sw. lort = Eng. filth), originally produced as a number of radio talks by Ludvig Nordström (1882-1942) during a journey through most of Sweden (Nordström 1938). Ludvig Nordström was a writer of realistic short stories and novels. During the 1920s and 1930s he had a strong belief in technical progress and peaceful evolutionism.

Actually "Lort-Sverige" was a report on the standard of housing conditions at the time, but it also touches on living conditions and the reasons for them. Let's start by approaching a house like Granströms:

He raised his face, dilated his nostrils, said:

- Smell!

I drew a deep breath through my nose.

- Indeed! It smells, it smells...

- It smells shit! Plain shit. Please, come back in July and $\mathrm{Mr}$ Nordström will really notice a smell. But now, let's look at something else. 
In the 1930 s the responsibility for the situation was seen like this:

(...) she cannot, like her husband, lie down on the bed or sit down with a tobacco pipe at the front-door landing, for she has to do the housework: cook the food, make the beds, clean the house, fetch the water, nurse the children.

- Slavery!

- Sheer slavery, no doubt. And you understand, what the house must look like in such circumstances.

- (. . ) The men have got their work, the stable, the forest, and the arable land. The women have got their work: the cowshed and the home. This ancient division of work causes the men never to help the women in their heavy work, not even when they are off work. It's a shame to do women's work.

- Previously it was always like that, the women tended the cattle quite alone, while the men did the outdoor work, and it would never do for the men, it would be a scandal, if they were to do housework, yet on the other hand,

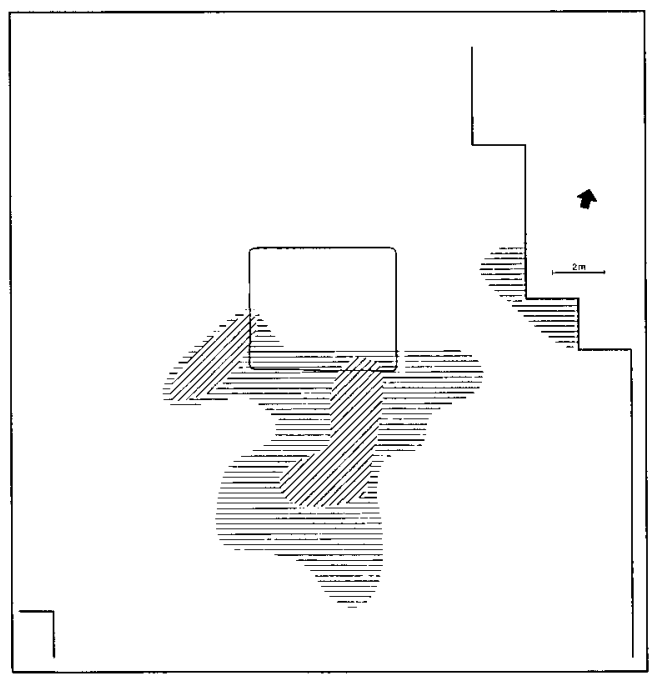

Fig. 7. The phosphate map of the cottage Granströms. Markers for $>50$ and $>100 P^{\circ}$. the women saw it as embarrassing, if they were to get help from the men.

Thus the gender-specific division of work was not just a functional one. It was integral to the gender identities, and it was upheld by social control. In the 1930 s this view was on its way to becoming explicit:

- Shall we talk about the garbage heaps, too?

- What about them?

- (. . .) He doesn't care. They just lie around! My Lord, flies and flies! We have done what we can, but the men are out doing their work, from sunrise to sunset, and we have got all our work. We cannot stand it any longer! We are exhausted!

(...) the men in Sweden do not show sufficient consideration for their wives and the importance of their housework and its hardships, and secondly, the young girls never know what lies before them, when they marry. Both these circumstances must obviously be changed, if the housing conditions are to be improved, because what I have seen today, and what I have previously seen during this journey, convinces me that the problems of housing conditions, at least from a straightforward human point of view, can simply be seen as the problem of the relation between the two sexes in Sweden.

I suppose that the mechanisms pinpointed by Ludvig Nordström in the 1930 s implicitly, unconsciously, and self-evidently were in function also at Granströms a century earlier, although in those days the village girls had few alternatives to that kind of life. In the 1930s they did have alternatives, and their choice enlightens what the phosphate map (Fig. 7) signifies:

This was the breakdown of the ancient worldview, which I had seen during all of my journey and which in the end meant that the women, 
which among primitive tribes usually were the slaves of the men, also in good old LortSverige were in fact looked upon in the same way.

Today the move by the women into the towns, away from the slaving in filthy kitchens and filthy cowsheds, perhaps ultimately means that they rebel against this slavery.

What then, do the daughters do? - Those girls! They are either moving to town or going to the folk high-schools (...)

\section{DISCUSSION}

\section{A landscape contains tension.}

In the previous section I have tried to understand a cultural landscape with the aid of a fluid concept of cottages and farms. A farm is a group of buildings, a piece of land, and a group of people, but it is also the use and conception of the landscape by that group of people. In the village of Nyberget in the 19 th century a dynamic population, a flexible architecture, and the fluid structure of cottages and farms formed a cultural landscape in continuous change.

Nevertheless, the village formed a landscape where people knew their ways and whereabouts. There were norms and rules implicitly known by everybody on how the village life was to be lived. I have tried to see the atom of the village as the nuclear family or as a related couple of one female and one male. In this small group, the population equivalent of a cottage or a farm, genderspecific work-tasks, roles, and power relations were at work.

In the fluidity of people and farms a system of social orientation made the village surveyable and gave it order and meaning to the villagers. This system can be understood from the place-names. Within the area of the single farm (Fig. 8) dozens of place-names denoted arable plots, meadows, the lake shore, rocks, hills, charcoal-stacks, buildings, mires, bogs, bends of the roads, gates, and so on, and so forth. The landscape was lived in together with scores of names. The names formed a landscape common to those who knew the names, and they formed a landscape alive with allusions and memories. That is, the place-names are what remain today of this way of living in a landscape, a man-made cultural landscape.

As the example of the grazing land of the Backans farm (Fig. 6) showed, the group of people that had a stock of place-names in common was far from the full village. There were other groups that subdivided the village in other ways. I remember once, when sitting together in a circle of sisters and brothers trying to localize place-names from the beginning of the century on the map, how the eldest sister leaned back in her chair and, when we were to start on the names in the forested part of their childhood farm, stated: "Now it's your turn, boys!". There are also agespecific names. A stream (Sw. bäck) in the central part of the village is called "Skolbäcken" (Sw. skola = Eng. school), because it runs close to the school. However, some of the middle-aged inhabitants of the village call it "Kräftbäcken" (Sw. kräfta = Eng. crayfish), indicating what the stream was used for by this group of people in their youth. The specific names of the various mineshafts were used only by a few. One of my informants gave me the reason in a rejoinder: "We just called the shaft, where they were working at the time, 'The mine'."

The social system of the totality of the village was reflected in the names of the cottages, farms, and persons. All cottages and farms had - and have - names, and all persons had - and have - names related to the cottages and farms: "Löv Verner" lived at "Löves", "Svens Anna" lived at "Svens" etc. People got their names from the place, where they were born or from the place where they lived. When people moved, they could get a new name related to the new place, or they could keep their name, or the place could sometimes acquire a new name from the person moving 
into the place. I dare give no rules for when the various alternatives occur. I have given some examples of the application of this system in the previous section. For the moment, the point is that places and persons have the same names.

Thus, when the name of a person was known, so was the place where she lived. Persons were identified as places, and places were identified as groups of people, normally nuclear-families. At the parish churchyard the markers simply have inscriptions with the name of a farm and a village within the parish. That is at the same time the name of a family, and that is what is important (Welinder 1991).

This system of social orientation is still in use. Listening to two parishioners talking is an amusing experience. When they talk about other people in the parish, they start by identifying the person by her family name and by persons related to her, which they both know. Next, they locate the person in question as to a village and a farm. Then they locate the farm by relating it to other farms known to both of them. Not until they are in agreement on whom the person is related to and where she lives, do they proceed by talking about the essential facts concerning the person in question. If persons and farms have the same name, things certainly become easier.

In this way the cultural landscape was and is - at the same time a social landscape. The landscape and its inhabitants, organized according to nuclear families related to cottages and farms, were - and are - one and the same.

A cultural landscape may be understood as an economic and social system in an ecological setting (e.g. Welinder 1983, 1984), or as the daily interaction of people in a tradition-bound setting. The latter is what I have tried to describe in this ethnoarchaeological study.

The Nyberget tradition can be described as the knowledge of how a proper village life was to be lived. I have tried to grasp the meaning of this tradition by analysing the cultural landscape of the village using the concepts of "gender" and "social orientation". To the villagers themselves the tradition was simply a knowledge of proper behaviour in a multitude of various worktasks and situations of social interaction, and it included a stock of place-names common to all villagers or some subgroup among them. The tradition was transmitted from generation to generation in the daily life within the cottage or farm unit of people, most often a nuclear family, and it was likewise transmitted to persons who had recently moved into the village through daily cooperation and chatting among the villagers.

Thus, the tension in the Nyberget cultural landscape is one between a variable physical landscape and a dynamic tradition. The tradition was dynamic inasmuch as it had to be continuously recreated in the daily interaction among the people of the village, but it was fixed inasmuch as its contents were a set of implicit rules of proper behaviour and power relations, which were more or less the same from generation to generation. The landscape was variable inasmuch as the landscape was a flexible one, where buildings and boundaries, cottages and farms were variable, but it was fixed inasmuch as the basic elements of the landscape from a conceptual point of view were the same for generations. The physical landscape and the tradition together form a cultural landscape - a landscape lived in by humans.

There is a need for a reservation. I have claimed that a farm, which has changed its boundaries, its farmyard, the boundaries around its land, its inhabitants, owner and name is still one and the same farm according to the village tradition. Since Nyberget is a village in a late historical period there is, however, also a governmental and clerical bureaucracy. This, perhaps even more than the villagers, needed order in the seemingly chaotic reality of the fluid landscape of 
cottages and farms. I will give a final example.

The oldest farm among the group of farms in the southwestern part of the village (Fig. 1) was called "Hagan". Later this name was adopted for that entire group of farms. The various agglomerations of farms within the village (Fig. 1) had names, often taken from the oldest farm of the group. In the late 17th century the owner of the farm Hagan was christened "Mikael". Among the villagers he ought to have been known as "Hag Mickel" or "Hagans Mickel". He grew very old and may have become a generally respected person. From his days onwards the farm is called

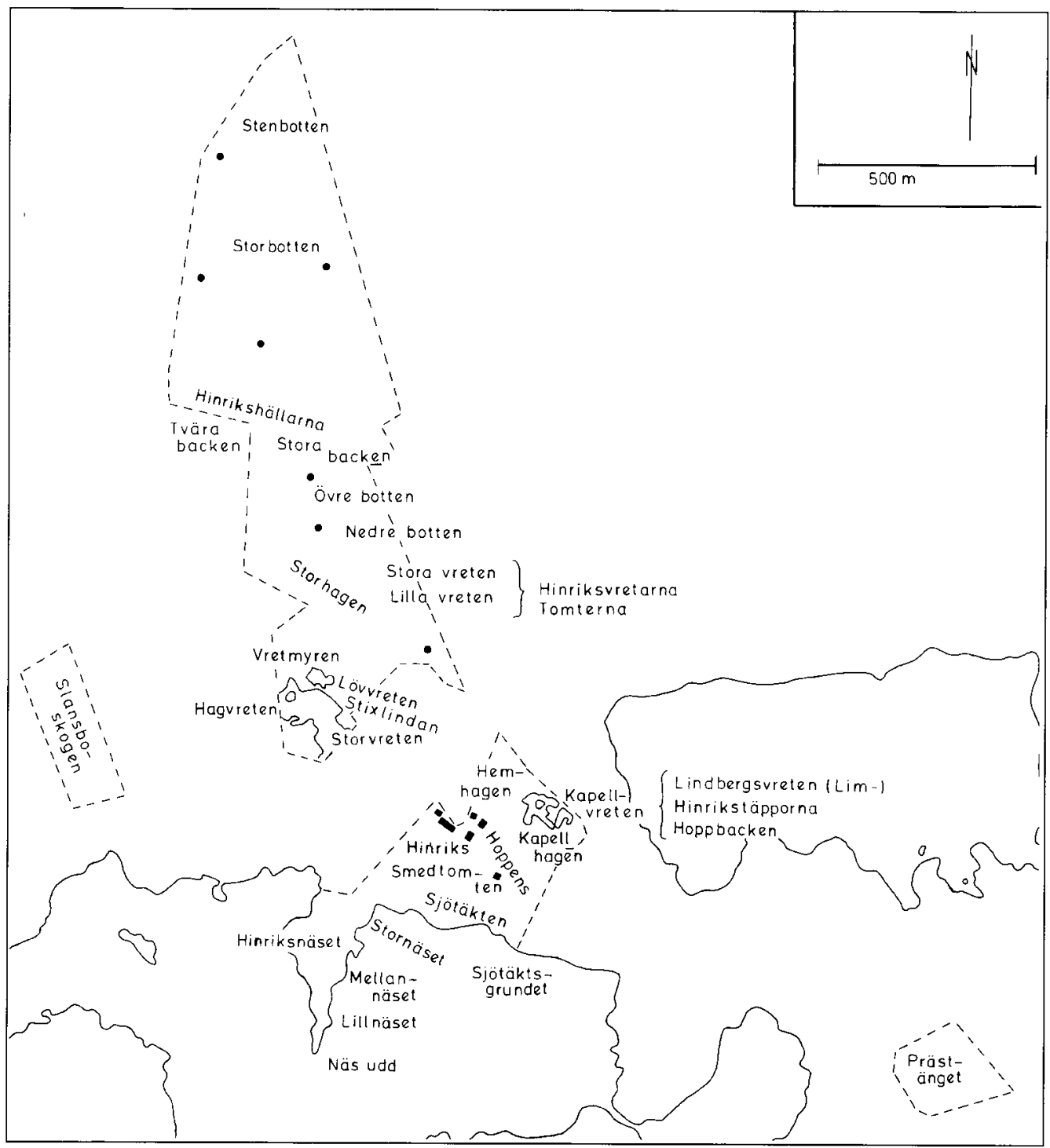

Fig. 8. Place-names used within the area of the farm Hinriks. The houses and charcoal-stacks, most of them with a hut, are denoted with black marks. 
"Mickels" (the inflective possessive of "Mickel"). In the middle of the 19th century the farm was bought by a man from outside the village, whose name was "Druckens Johan" in his home village. After that the farm was mostly called "Druckens" among the villagers, but in the parish register it was still called "Mickels" for another century. During the enclosure movement the farmyard was moved a few hundred meters to the centre of the newly delimited land. Around the turn of the century, the farm had turned into a cottage in the view of the villagers. In the cottage there lived two persons, an old woman and her foster-daughter. The woman was called "Druckens Moster" by some, and "Mickels Moster" by others (Sw. moster = Eng. maternal aunt, another example of the tendency to relate persons to other persons). The husband of the daughter built a new house in the 1920s. This was, and still is, regarded as a farm by the villagers, called "Hammars" after the name of the son-in-law. Today it is no longer an agricultural unit but the dwellinghouse of a commuter. The cottage (Sw. stuga) is still there, called "Druckens" or"Lillstugan" (Sw. $\operatorname{lill}(a)=$ Eng. small).

\section{RESEARCH STRATEGY}

Already V. Gordon Childe in 1958 wrote (1958:73):

Incidentally $I$ realized that the environment that affected a prehistoric society was not that reconstructed by geologists and paleoecologists but that known or knowable by the society with its then existing material and conceptual equipment.

In the modern debate, the insight that a landscape inhabited by humans is not just a landscape adapted to or exploited by humans, is inherent in the use of the concept of "social space" (Grön et al. 1991). A landscape is turned into a cultural landscape both by humans changing the landscape and by humans living in the landscape and regarding it as their environment. "Social space" is the landscape seen as organized and lived in by humans. The social space of the humans is the scene and the instrument of their interaction.

Discussing a landscape as social space aims at understanding the landscape as human interaction. It is not merely the result of human action but also the conceptual world inherent in human interaction.

The discussion of social space or a cultural landscape, in which the term "cultural" denotes culture in a deep sense of human creativity and variability, presupposes a view of the landscape from the inside. Viewing a landscape from the outside (Alfvén \& Alfvén 1969) means recording and measuring and explaining from the application of ecological, demographic, and social theories following statistical and experimental interference. Viewing a landscape from the inside means trying to understand the landscape as human hustle and bustle.

A phase of ethnoarchaeological discussion is basic to the moulding of the necessary ideas and concepts. I regard my study of the Nyberget village as a part of such a discussion.

\section{PREHISTORIC ARCHAEOLOGY}

Ethnoarchaeology has two aims:

1) To discuss how humans and things interact, or, phrased in a different and perhaps better way, how humans interact in a physical environment.

2) To construct and discuss ideas and con cepts to be used in the study of prehistoric archaeology.

So far in this article I have concentrated on the first of the two above points. Of course there is a duty to attempt the second one, too.

The prehistoric cultural landscape may be recorded and reconstructed from fieldwalking, excavation data, and from a variety of paleoecological data (Welinder 1988). To 
approach the full mobility of a group of prehistoric humans within their landscape and how they experienced the landscape as social space, possibly in several different ways within the same group, may seem a utopian task. It is difficult enough as a temporary ethnoarchaeological participant in a present-day society.

Conducting ethnoarchaeology in a historical society like 19th-century Nyberget is half a step towards prehistory. It is a critical half step inasmuch as I cannot talk to the members of the society themselves and I cannot observe them in action - and interaction - in their cultural landscape. But a crucial half step is still left, although they are not totally silent. I have chosen to examine how place-names were used at the turn of the century (Figs. 6, 8) and how the names of persons and houses are still linked to one another as the experienced landscape of the 19 th-century Nyberget villagers. The placenames provide a view of an ambiguous system of orientation with respect to both the daily landscape lived in by the villagers and their comprehension of the village as a whole.

Ethnoarchaeology generates questions, and, after all, isn't that what is needed in prehistoric archaeology, i.e. interesting ways to put questions? In this ethnoarchaeological study I have tried to understand a cultural landscape as both dynamic flexibility and a fixed tradition, as both ambiguity and a set of norms. That's the challenge to prehistoric archaeology.

English revised by Laura Wrang.

\section{REFERENCES}

Alfvén, H. \& Alfvén, K. 1969. M-70. Stockholm. Binford, L.R. 1983. In pursuit of the past. London. Blomkvist, N. (red.) 1990. Kulturmiljö. Historien i landskapet. Stockholm.

Childe, V.G. 1958. Retrospect. Antiquity 32 (6974).

Erixon, S. 1960. Svenska byar utan systematisk reglering. En jämförande undersökning 12.Stockholm.

Eskeröd, A. 1965 (1953) Arets fester. Stockholm.

Gould, R.A. 1989. Ethnoarchaeology and the past: our search for the "real thing". Fennoscandia archaeologica 6 (3-22).

Grön, O., Engelstad, E. \& Lindblom, I. (eds.) 1991. Social space. Human spatial behaviour in dwellings and settlements. Odense University Press, Odense.

Hage, B. (P. Gustafsson) 1946. Bygd och människor i Dalarna. Hedemora.

Hjørungdal, T. 1991. Det skjulte kjønn. Patriarkal tradisjon og feministisk visjon belyst med fokus pa en jernalderkontekst. Lund.

Hodder, I. 1986. The present past. An introduction to anthropology for archaeologists. London.

Kelley, J.H. \& Hanen, M.P. 1988. Archaeology and the methodology of science. Albuquerque. Moore, H.L. 1986. Space, text and gender. An anthropological study of the Marakwet of Kenya. Cambridge.

Nordström, L. 1938. Lort-Sverige. Stockholm.

Patrik, L.E. 1985. Is there an archaeological record?Advances in Archaeological Method and Theory 8 (27-62).

Watson, R.A. 1991. What the New Archaeology has accomplished. Current Anthropology 32, 3 (275-291).

Welinder, S. 1983. The ecology of long-term change. Lund.

- 1984. A systemic approach to understanding longterm change in a cultural landscape. $B A R$ Int. Ser. 211 (1-25).

- 1988. The landscape of prehistoric man. Memoranda Societas Fauna et Flora Fennica 64 (50-56).

- 1991. "Reflections Written in a Country ChurchYard". Acta Archaeologica Lundensia. Ser. in $8^{\circ}, 20 .(347-355)$.

- 1992a. Människor och landskap. Uppsala.

- 1992b. Människor och artefaktmönster. Uppsala. 
